\title{
The Avengers and the PLA Wolf Warrior: Popular Narratives and Major Power Competition
}

\author{
Benjamin Tze Ern $\mathrm{Ho}^{1}$
}

Received: 12 October 2021 / Accepted: 26 February 2022 / Published online: 7 March 2022

(C) The Author(s), under exclusive licence to Springer Nature B.V. 2022

\begin{abstract}
In recent years, some scholars of international politics have argued for the need to integrate the use of visual media into our understanding of global politics. In this respect, film (or movies) represents an effective media of communicating powerful ideas and political worldviews through a smorgasbord of sound and sensory experiences. This essay seeks to draw on the theoretical insights of scholars of visual international politics to analyze the ongoing geopolitical conflict between the United States and China. It will do so by examining two box-office hits in the West and China, namely, the Avengers and Wolf Warrior. Through a study of some of the key storylines in these films, this essay seeks to flesh out the differences in Sino-Western conceptions of patriotism, good and evil, and salvation. It argues that these differences are not just a matter of aesthetic preferences, but reflect more fundamental ideas and political worldviews salient in the thinking of China and the West.
\end{abstract}

Keywords United States · China · Visual IR · Wolf Warrior · Diplomacy

"This is the fight of our lives. And we're going to win. Whatever it takes." (Steve Rogers as Captain America, Avengers: Endgame)

"Even if there's a small chance, we owe this to everyone who is not in this room." (Natasha Romanoff as Black Widow, Avengers: Endgame)

“Those who offend China will be punished even if they are far away" (犯我中 华者虽远必诛)

(Leng Feng, Wolf Warrior 2)

"You think the US Marines are the best in the world? Where are they now?" (Leng Feng, Wolf Warrior 2)

Benjamin Tze Ern Ho

isteho@ntu.edu.sg

1 S. Rajaratnam School of International Studies, Nanyang Technological University, Singapore, Singapore 


\section{Introduction}

Films - as cultural artifacts- have long been recognized for their relevance to international politics and as a medium of political communication and social commentary [11]. To this end, the topic of international conflict and war is an evergreen theme of box-office interest, a reflection of the perennial character of conflict which continues to interest and intrigue people all over the world. ${ }^{1}$ At the same time, given our post-literate age, most people get much of their information about international affairs from films, or more broadly, from visual media. As William Callahan puts it in a recent study on the role of visuals in international relations, "because visuals can viscerally move us in unexpected ways...they need to be appreciated not just in terms of their ideological-value, but also in terms of their affect-work; not just what they mean, but also how they make us feel, both as individuals as collectives" [8].

With this backdrop in mind, this paper seeks to interrogate the geopolitical conflict between China and the United States through a comparative analysis of two films which-as I will argue-proffer us important insights into the political worldview and cultural identity of the two super powers. Through an analysis of the Avengers: Endgame (2018) and Wolf Warrior 2 (2017), this essay seeks to flesh out the varying conceptions of patriotism, good and evil, and salvation that are being narrated in both films and what they tell us about the political character and ideological beliefs of China and the West (or America). I chose these two films as a point of contrast for several reasons:

Firstly, both Avengers: Endgame and Wolf Warrior 2 were box-office successes, thus suggesting that their storylines and themes have box-office appeal, and thus speak to a broad audience's view of their country's ideals. In the case of Endgame, the film grossed $\$ 858.4$ million in the United States and Canada and \$1.939 billion outside North America for a worldwide total of \$2.8 billion, making it the highest grossing film of all time (before adjusting for inflation). ${ }^{2}$ Interestingly, the film was also the highest grossing foreign film of all time (\$629.1 million $)^{3}$ in China and fourth highest overall, an indication that its themes had also universal appeal beyond North America. In the case of Wolf Warrior 2 (zhanlang er 战狼二), it was the highest grossing film of all time in China (\$874 million) and was the first and only Chinese film ever to be included in the list of the top 100 all-time highest grossing films worldwide, including being the highest grossing non-English film of all time. ${ }^{4}$

Secondly, both movies deal with themes of international conflict and specific responses to these conflicts. In the case of Avengers: Endgame, a group of superheroes (the Avengers) is required to put aside their differences to take on the evil

\footnotetext{
1 One such estimate puts the number of films made about the Second World War at more than 1,300 films. See https://www.theguardian.com/film/2014/jul/17/why-so-obsessed-second-world-war-films and https://en.wikipedia.org/wiki/List_of_World_War_II_films\#Late_1980s (retrieved February 20, 2022).

${ }^{2}$ https://en.wikipedia.org/wiki/Avengers:_Endgame

3 https://en.wikipedia.org/wiki/List_of_highest-grossing_films_in_China

${ }^{4}$ https://en.wikipedia.org/wiki/Wolf_Warrior_2
} 
villain Thanos, and to save half of humanity which had disintegrated following the events of an earlier film. ${ }^{5}$ In Wolf Warrior 2, it tells of China's deadliest special forces operative Leng Feng who after settling into a quiet life on the sea was forced to leave his idyllic lifestyle and return to his role as a soldier as a result of attacks against medical aid workers by vicious arms dealers. As a sequel to an earlier film, ${ }^{6}$ it portrays Leng Feng as part of the "Wolf Warrior" unit, an elite unit within the People's Liberation Army (PLA) charged with the task of simulating foreign tactics for the PLA to train against. As this essay will show, embedded in the narratives of both films lie deeper questions of duty, loyalty, and the struggle of good versus evil. This dovetails well with our study of international conflict which often involves decisions made that necessitate the need for war, and violence, in order to preserve the greater good. While it is beyond the scope of this essay to provide a comprehensive answer to the conditions that would be necessary and legitimate to prosecute war, these films allow us to appreciate-from a comparative, and aesthetic perspective- the similarities and differences in the nature of conflict, the responses that are needed, and how violence in the service of the greater good is being justified.

Thirdly, the choices of the heroes in both movies are also being held as models and paragons of idealized virtue. While this essay is not meant to be an in-depth study of the film characters, nevertheless, the traits exhibited by the film protagonists provide us with some clues as to the desired qualities of a hero and what they tell us about the wider socio-political values of the societies they purport to represent. In the case of Avengers: Endgame, I will look at Captain America (portrayed by Chris Evans) and also Iron Man (Robert Downey Jr.) and how these two key protagonists reflect certain qualities and personal attributes that are seen as heroic and worthy of emulation in the West. In the same way, Leng Feng-as the soldier par excellence-provides us with some clues concerning the type of person and qualities that are desired in Chinese political culture and that of the archetype patriot. How do these characteristics (or virtues) inform our understanding of American (or more broadly, Western) and Chinese societies and the values that are idealized? How do these attributes fit within the broader political narrative(s) permeating these societies, and to what extent are these ideals reflective of more basic differences existing between them, and the existence-if any — of common ground that can be found?

The remaining of this paper will be as follows. First, I will provide a brief introduction of the literature linking visuality to international politics and how they provide us with interesting ways of picturing, indeed visualizing, the practice of international relations and more importantly, the meanings behind those practices. Next, I go on to examine both films using a comparative approach focusing on how the themes of patriotism, good and evil, and salvation are being constructed and consequently visualized. Finally, I conclude with some reflections on how such an analysis can provide scholars of international relations (especially scholars of SinoAmerican politics) to critically examine our own assumptions concerning self-other

\footnotetext{
5 As depicted in the film, Avengers: Infinity War (2018), https://en.wikipedia.org/wiki/Avengers:_Infin ity_War

6 As depicted in the film, Wolf Warrior (2017), https://en.wikipedia.org/wiki/Wolf_Warrior
} 
identities and the extent to which films can provide us with new ways to reframe our understanding of great powers relations and a more realistic appraisal of geopolitical rivalry.

\section{The Visual Turn in International Relations: Moving from Text to Images}

Since Roland Bleiker's declaration of an "aesthetic turn" in IR theory in 2001 [3], a number of critical scholars have attempted to utilize the insights proffered by Bleiker to make sense of changes in the global political landscape and more importantly, how best to interpret political phenomena including the ideologies behind them. Among them, William Callahan's exposition of the necessity to "visualize" international relations instead of being confined within parameters of textual discourse represents a useful vantage point with which to anchor my subsequent analysis [8]. As argued, visual artifacts are more than illustrations of ideology and that they possess agency, including the power to "do" things and "make" things. Instead of just illustrating international events as visual texts, visual images can "actively create international politics as visual performance that viscerally move and connect people in unexpected ways" [8]. Relating this to the practice of film-making, Callahan further observes that it provides a means to explore the "intricacies and intensities" of how politics works through "self/Other relations" as "state-to-state relations interact with people-to-people relations through experiences of hospitality, estrangement, intimacy and vulnerability." "Seen this way, we can go beyond seeing and framing international politics in terms of ideology to appreciate its "affective register," or as one critique of rational knowledge puts it, filmmaking can provide a "mode of thought better than knowledge" for understanding international politics [8].

Before we go on to examine the afore-mentioned two films, several caveats are in order. Firstly, cynics might dismiss film as cultural propaganda, be it Western or Chinese in origins, and thus dismiss anything of value that can be said about it. Such a line of argument is necessarily simplistic and unconvincing for it forecloses opportunities to engage in a deeper and more considered understanding of the ideational conditions that frame how actors (and states) think and act in their international politics. A second caveat is that this essay does not attempt to figure out exactly what the director/media companies had in the production of the film. Among media practitioners, there is often an inevitable desire to try and plough through media products to uncover the actual reality of what lies behind the film, or in other words, what the director of the film really had in mind in making a particular film, or to film a particular scene. This is not to say that one can indulge in infinite interpretive speculations; indeed, I assume there was really an answer-or reality-that a filmmaker hopes to narrate except that this is not the intention of the essay to find out. Furthermore, the possibility that other meanings may also surface in the process of interpretation which may evade the original intention of the film producer suggests the hermeneutics of film may be more problematic that is originally supposed since

\footnotetext{
${ }^{7}$ It is noted that Callahan draws on his experience of research filmmaking which is different in some aspects from making films for mass consumption.
} 
authorial intent may not be the only source of data concerning the meaning of a film. Finally it should be said-for all intentions and purposes - that I do not view these films as simply "pure entertainment" though I suppose one could do so and still draw similar conclusions as I do. But as Callahan and others have observed, filmsas cultural products - are also sites of contestation (intended or otherwise) and it behooves scholars of international relations to examine them closely to uncover some of the basic themes and ideas they purport to tell us and how these speak to broader issues and debates concerning global politics [14, 23].

\section{Avengers Endgame: From Universal Conflict to American Leadership}

Clocking in at $181 \mathrm{~min}$, the Avengers: Endgame (2019) is a direct sequel to the 2018 film Avengers: Infinity War as the surviving Avengers and their allies seek to reverse the damage caused by the villain Thanos in Infinity War in which half of humanity had disintegrated. To do so, the Avengers had to travel back in time to obtain six infinity stones - which Thanos had earlier possessed and used-before an earlier Thanos could retrieve them. After doing so, the Avengers reunited in the present and were able to reverse the disintegration; however, Thanos was able to travel to the present, bringing along together his entire army. The Avengers and their revived allies thus wage a final battle with Thanos and his forces and defeat them. The victory however was not without cost, as two of the main characters among the Avengers lost their lives. Tony Stark (aka Ironman) sacrificed his life in order to defeat Thanos while Natasha Romanoff (Black Widow) also lost her life earlier in the film in the course of retrieving one of the infinity stones (the Soul Stone). As a film, Avengers: Endgame deals with the familiar theme of conflict and war, on a global scale no less, and other common interrelated subtopics such as universal redemption, the pursuit of unity (despite individual differences), and the need for personal sacrifice. From the vantage point of the three themes we have highlighted earlier (patriotism, good vs evil, and the issue of salvation), Endgame allows us to appreciate-from a visual perspective- - how these themes are being understood, framed, and played out within the film narrative.

As a major character, Captain America personifies the American Hero (or at least a highly identifiable archetype of such a hero) and calls to mind the quintessential ideal of what it means to be a patriot of the American state. In the words of Steve Rogers, the war against Thanos was the "fight of their lives and we are going to win, whatever it takes." Interestingly, this emphasis on the collective ("we") instead of the individual ("I") challenges dominant stereotype of the United States as a highly individualistic society and where rugged individualism is often celebrated as a virtue [1]. In the case of the Avengers, it was evident that no one single individual had the ability or capacity to defeat Thanos. Furthermore, all of them possessed certain character flaws which rendered them imperfect superheroes. ${ }^{8}$ In Captain America's instance, this imperfection is juxtaposed alongside his determination to succeed in

\footnotetext{
8 This is being fleshed out in the movie The Avengers (2012) as well as in the previous Marvel films featuring the characters in their individual roles.
} 
his mission at all costs, thus resulting in him having to forego the well-being to his personal love-life ${ }^{9}$ and also having to insist on the correctness of his political ideology even if it means having to confront one's own allies. In the latter, this was being played out in the movie Captain America: Civil War (2016) in which the Avengers were being divided against one another, with one camp aligning with Steve Rogers and the other with Tony Stark (Iron Man). Be that as it may, these internal divisions - in American political life-can be placed aside in the service of a greater good when the need arises and collective cooperation takes precedence over individual self-pursuit. This is suggestive of a broader ideational vision of what a patriot entails which, contrary to popular narrative, does not insist the pursuit of individual objectives at all costs. As observed by George McKenna, the sources of American patriotism can be traced back to Reformation Protestantism resulting in an activist theology which stressed collective rather than individual salvation [19]. At the same time, and given the film's premise of worldwide war, being America's patriot is portrayed not as narrow nationalism, but also evinces a broader responsibility to the wider community, even if the outcomes may not always be what Washington had originally planned or hoped for.

To be certain, the influence of Machiavellian politics (and the often cited phrase "there are no permanent friends or permanent enemies, only permanent interests") has generated a deep distrust concerning the viability of international cooperation and whether patriotism can co-exist with the objective of being a global citizen. That said, the notion that a state's ultimate responsibility to its citizens and citizens alone may not be only viable paradigm accounting for state sovereignty and subjectivity. In Tan's study of the political regimes of Southeast Asian states (many who are fiercely protective of their own national sovereignties), it was proposed that Emmanuel Levinas' concept of responsibility provided an alternative vision to explain the need for cooperation without being trapped in instrumental or utilitarian logic. As observed, "the most visibly apparent overarching theme in Levinas' thought is responsibility - not to the self but to and for the other. In contrast to the Enlightenment-inspired notion of being as autonomous, given, and therefore sovereign, Levinas understood it as a radically interdependent condition... responsibility to the other therefore comes before everything else" (italics mine) [28]. Specifically, individuals are also being constructed by way of their relationship with and to the other, an ever-present indebtedness to the other that marks and defines one's very own identity and subjectivity [28]. Seen this way, one might then say that patriotism or devotion to one's country is not necessarily at odds with the commitment to the wider world. On the contrary, being a patriot requires one to look beyond the frontiers of one's own nationality and to consider a broader definition of citizenship, indeed as a "global citizen" and the obligations which such citizenship entail, even if there are no immediate, discernible benefits to oneself. As quipped by Black Widow, "even if there's a small chance [of success], we owe this to everyone who is not in this room."

\footnotetext{
9 As depicted in the movie Captain America: The First Avenger (2011).
} 
Secondly, as far as the discussion of good versus evil is concerned, Endgame at first glance possesses a fairly basic plotline with the Avengers and their allies being on the side of good while Thanos and his forces on the side of evil. Yet a closer examination suggests that this seemingly straight-forward storyline belies a deeper moral narrative: one is good or evil not because of anything inherent, but as a result of the choices one chooses to make. While this runs against the Augustinian theology of original sin which shades much of Western thinking [5], ${ }^{10}$ at the same time, human beings - as moral agents - are also responsible for their own actions. In the case of Thanos, his murderous actions were justified by the need to eliminate half of humanity so as to preserve the other half ("by eliminating half of life, the other half will thrive") and presumably with the goal of making himself the savior of those alive who will in turn express gratitude to him ("[I will] create a new [universe]. Teeming with life, but knows not what it has lost but only what it has been given. A grateful universe.") On the contrary, the Avengers justified their quest to reclaim the stones — and the potential loss of life the quest would entail—to bring back those who were lost. Seen this way, heroic actions are evidenced by the willingness to lay down one's own life for others while villainous actions are defined by the inclination to use-even sacrifice-others to achieve one's own ends (no matter how noble these objectives might be). From this, we see that categories of good and evil are not ontological ones, but rather they derive from how individuals choose to act upon their external world. Moral agency is never absent from the individual self, good and evil are the results of individual actions, and not because of anything inherent. This element of moral agency is further amplified by the fact that members of the Avengers were often portrayed as imperfect individuals throughout the Marvel Universe films ${ }^{11}$ and yet were able to act rightly and sacrificially in the hour of need. Likewise despite his actions, Thanos possesses some redeeming factors, notably in his relationship to his daughter Gamora whom he sacrifices in the Infinity War in order to procure the Soul Stone. While this may seem ironical, the fact that Thanos retains a soft spot for Gamora suggests that he may not be wholly evil. Indeed, this intricate interplay of good and evil in the world brings to mind the words of the Russian novelist Aleksandr Solzhenitsyn that reality is far more complicated:

The line separating good and evil passes not through states, nor between classes, nor between political parties either - but right through every human heart...even within hearts overwhelmed by evil, one small bridgehead of good is retained. And even in the best of all hearts, there remains....an uprooted small corner of evil. [27]

\footnotetext{
10 The eighteenth-century American preacher Jonathan Edwards also made a similar argument in his theological treatise Freedom of the Will, http://www.reformedreader.org/rbb/edwards/fowindex.htm (retrieved August 18, 2020).

11 For instance, Iron Man is an alcoholic and womanizer while the Hulk has a problem controlling his anger. In Avengers: Endgame, the warrior Thor was being shown as having a drinking problem while Hawkeye descends into a life of killing following the disintegration of his family.
} 
Thirdly, the issue of salvation or redemption arguably lies at the heart of the Avengers: Endgame. To the question of what does it take to save the lives of others, the answer is unequivocal, that is, "whatever it takes," a line repeated three times in the film. While this may be self-evident at first glance, the context of the film suggests a deeper, even spiritual, meaning from which the answer is framed within. Unlike most Hollywood films in which the hero frequently survives, Endgame furnishes us with a plot twist in which the hero of the film, Tony Stark (Iron Man), sacrifices himself at the end in order to defeat Thanos. The fact that Iron Man had earlier expressed his reluctance to return to his Avengers-fighting days as a result of him settling down with Pepper Potts and having a daughter further amplifies the sense of loss.

Relating to the above themes discussed, namely, patriotism, good-and-evil, and redemption, I argue Avengers: Endgame reflects first and foremost a quintessential Western portrayal of universal values, which is most emphatically linked to the values that are desired by America. The leading role played by Captain America in the film is certainly no coincidence if we consider that Steve Rogers-in his character-exemplifies the qualities that are often idealized in an American hero, that of a patriot and the sacrifices that must be made in order to become one. But more than that, it can be said that Endgame puts forth another political proposition, in that American values are universal because they are inherently attractive to the world. Ever since Joseph Nye's exposition of soft power as a means of success to world politics, American soft power has frequently been touted as a crucial element in promoting America's influence worldwide [20]. Whether one believes it or not and whatever the criticisms of American waning soft power influence, particularly during the Trump administration, claims to universality have always been a hallmark of American political worldview. This is most vividly emphasized by liberal scholars who view the promotion of free market principles and strengthening international institutions as key features of the global international order. As the argument goes, liberal thinkers consider the pursuit of political and economic freedom as a universally desired goal and the role of the United States both as an enabler and exemplar in the quest for such an objective [17]. In this respect, to be an American patriot is - at its core-seen to be synonymous with being a good global citizen and what is seen as good for America is also viewed as being generally good for the world.

Such a mindset naturally also sees the issue of good-versus-evil as not one of between states (as if there is something inherent in a state that can be considered "evil" or "good), but rather one that is being fought at a metaphysical level (hence Thanos who is personified as a villain without origins or ancestry) that goes beyond interstate or intrastate conflict. In this respect, the United States-as epitomized by Captain America-is seen to be leading the fight against evil, building a coalition of unlikely, even unruly allies (as the complicated relationships between the Avengers go) in standing up for good against the evil forces of the world (who are portrayed as being blindly loyal to Thanos). Indeed, if we recall the "axis of evil" coined by George W. Bush in his war on terror campaign or Ronald Reagan's "evil empire" during the Cold War against the Soviet Union, the worldview of the United States is one which sees international conflict as reflective of a perpetual Manichean conflict 
between good and evil with American ideals as emblematic of the former while the beliefs of its enemies are taken to be of the latter [16].

The issue of redemption - as a form of closure-is also a crucial aspect of the United States' political worldview, not least because of the need to win votes by means of generating a sense of well-being and happiness among the American polity. Indeed, the notion of personal redemption is-in the author's viewone of the most salient themes in all of America's film culture, as evidenced by the popularity of the film The Shawshank Redemption, a movie which traces the story of two imprisoned men whose lives and friendship with one another allow both to obtain redemption amidst the harsh conditions of prison [13]. As observed by Shulman, race and redemption represent constant themes in American political thought, in which ancient biblical prophecy is used to interpret and frame issues of contemporary American politics, including the idea of American exceptionalism:

For the idea of a chosen people and "redeemer nation", called to redeem all humanity from despotism and immorality, resonates even avowedly secular citizens. Such redemptive language entwines democracy and a special American nationhood: Only forty years ago, Martin Luther King Jr. invoked redemptive language to cast racial apartheid as a national failure to honor a democratic promise; now evangelical Republicans narrate a "jeremiad" depicting the nation decline from its sacred and virtuous origins. Both draw on a deep symbolic structure and prevailing narrative form to name the circumstances, confront the vicissitudes, address the meaning, and authorize the reconstitution of collective life. [26]

From this vantage point, we might say the United States, in its practice of international politics and diplomacy, is imbued with the same zeitgeist that characterizes its vision of domestic political life: America perceives itself as a redeemer nation of the world and consequently considers itself as having a moral authority to right the world of wrongs. Indeed, this impulse to act on the side of good (whether others agree American actions are good or otherwise is beside the point) has its roots in religion, as Andrew Preston argues.

"Religion acted as the conscience of American foreign relations. U.S. foreign policy itself has never really been idealistic and certainly not altruistic. But policymaking elites often had to pursue foreign policy initiatives under an idealistic banner because of popular religious pressures that were themselves idealistic. They had to merge the moralism and progressivism of religion with the normally realist mindset of international politics. Thus the U.S. government was often led to pursue a normative foreign policy...by religious pressures emanating from below". [21]

Summarizing the above discussion, we see that Avengers: Endgame-as a discursive text-provides us with some important insights into the characteristics of American political culture and consequently its assumptions and thinking into international politics and foreign policy. The themes of good-and-evil, patriotism, 
and redemption continue to frame the way in which the United States view itself and its responsibilities to the world. While American global leadership has come under increased scrutiny of late, particularly during the Trump's administration, the themes uncovered in this essay suggest that Washington is unlikely to abdicate its claims to international primacy and to pursue its interests in ways that are radically dissimilar from the past. Indeed, President Biden and senior members of his administration have all articulated their views of how they view America's place in the world, including maintaining American leadership and promoting values of democracy and freedom through its foreign policy in very much the same vein and language of previous administrations (sans Trump) [2, 10]. To this end, the United States sees China as its biggest geopolitical challenger, and which we will turn to next.

\section{Wolf Warrior: an Uncompromising Vision of Chinese Strength and Superiority}

The topic of Wolf Warrior diplomacy was brought vividly to public consciousness in 2020 during the height of the coronavirus pandemic when the Chinese foreign ministry embarked on a series of hard-hitting public statements in response to international criticism and blame over Beijing's initial cover up of the coronavirus when it first started. Notably, Zhao Lijian, who is the deputy director of the China's foreign affairs ministry and its spokesperson, was prominently featured. In his tweets and comments, Zhao called the United States to apologize for saying China was responsible for the coronavirus and he also promoted a conspiracy theory accusing the United States military as being responsible in bringing the virus into China during the Wuhan military games in late 2019. ${ }^{12}$ As observed by Suizheng Zhao, "Chinese diplomats used to be known for their low profile and courtesy but now known as wolf warriors (战狼), derived from the 2018 Chinese movie 'Wolf Warrior' in which a Chinese special-operations fighter defeated Western-led mercenaries and became a national hero for defending China's overseas interests. No longer emphasizing diplomatic protocol, Chinese diplomats competed to demonstrate a tougher attitude, offensive tone, and more confrontational cruel and ruthless against foreign rivals. The emphasis on fighting (or struggling) highlighted one of the new features of Xi's foreign policy, conceiving diplomacy as a war against enemy forces that must be defeated" (italics mine) [30].

Seen this way, the film Wolf Warrior and its sequel (Wolf Warrior 2) provide us with an interesting vantage point with which to understand how this idea of struggle (douzheng 斗争) is now being incorporated into the China's foreign policy lexicon, least of which is in China's response to what it perceives as externally Western-fashioned attacks on the CPC's political legitimacy to rule China. To be certain, this Wolf Warrior form of aggressive diplomacy is not an entirely new development, but rather reflects an evolution of Chinese diplomatic stance. As Peter Martin explains, Chinese diplomacy was "modelled on the military force that had propelled the

\footnotetext{
12 Zhu, Zhiqun. "Interpreting China's Wolf Warrior Diplomacy." The Diplomat, May 15, 2020, https:// thediplomat.com/2020/05/interpreting-chinas-wolf-warrior-diplomacy/ (retrieved March 9, 2021).
} 
Communists to power: the People's Liberation Army...They would be combative when needed and disciplined to a fault. They would instinctively observe hierarchy and report to their superiors on everything they did...Most important, the idea of working as a 'civilian army' underscored the fact that the first loyalty of Chinese diplomats would always be to the Communist Party" [18]. Given this backdrop and China's current international prominence, Chinese scholar Yan Xuetong characterized Beijing as moving from keeping a low profile to striving for achievement in its foreign policy, and seeking parity with the West [29]. In addition, a number of outspoken Chinese scholar-practitioners such as Zhu Chenghu and Liu Mingfu (both PLA senior officers) have made strong remarks against the West in their own writings over the years. For instance, Zhu, who heads the PLA National Defense University, said as early as in 2005 that "if the Americans draw their missiles and positionguided ammunition on to the target zone on China's territory, I think we will have to respond with nuclear weapons [and] we will prepare ourselves for the destruction of all of the cities east of $\mathrm{Xi}$ 'an. Of course the Americans will have to be prepared that hundreds ... of cities will be destroyed by the Chinese." 13

Notwithstanding these fighting words, Chinese foreign policy rhetoric-up till 2017 or so-had remained relatively guarded. As a point of comparison, the first Wolf Warrior movie which was screened in the spring of 2015 made little impact in the Chinese box office (grossing US\$89 million) and did not even feature in the top 10 box-office hits in the Chinese domestic market. Wolf Warrior 2 however, which was released in the summer of 2017, was an astounding domestic success selling about 159 million tickets at the Chinese box office. What accounts for this sudden turn in fortunes given that both films - in terms of genre and style-are similar? One possible reason - at least in the author's mind - is that while the first film is mostly about China defending its borders from external aggressors, the second film situates China interests within an international, more expansive context in which Beijing is portrayed as fulfilling its responsibilities as a global great power. According to the male protagonist and film director $\mathrm{Wu}$ Jing in an interview with journalist Evan Osnos, "in the past, all of our movies were about, say, the Opium Wars-how other countries waged war against China... but Chinese people have always wanted to see that our country could, one day, have the power to protect its own people and contribute to peace in the world." ${ }^{14}$ Indeed, I argue that Chinese foreign policy circa 2016 has placed a greater premium on China's global contribution, including its claim to be a good citizen of the international community. ${ }^{15}$ According to Tiang Boon Hoo, China's global identity is related to its own identification as a

\footnotetext{
13 Cited in, Lieggi, Stephanie. "Going Beyond the Stir: The Strategic Realities of China's No-First-Use Policy." Monterey Institute of International Studies, The Nuclear Threat Initiative, January 1, 2005, https://www.nti.org/analysis/articles/realities-chinas-no-first-use-policy/ (retrieved March 12, 2021). See also, Liu Mingfu. The China Dream: The Great Power Thinking and Strategic Positioning of China in the Post-American Era, trans. (Beijing: CN Times, 2015).

14 Osnos, Evan. "Making China Great Again." The New Yorker, January 1, 2018 https://www.newyorker. com/magazine/2018/01/08/making-china-great-again (retrieved March 12, 2021).

15 One of the key foreign policy slogans of President Xi is the idea of a Community of Shared Future for Mankind (renlei mingyun gongtongti 人类命运共同体).
} 
Table 1 Differences between Avengers: Endgame and Wolf Warrior 2

\begin{tabular}{|c|c|c|c|}
\hline & Nature of good and evil & Patriotism & Redemption \\
\hline Avengers: Endgame & $\begin{array}{l}\text { Taking place at a cosmic } \\
\text { level. Comprises of } \\
\text { metaphysical dimen- } \\
\text { sions. Individuals have } \\
\text { to make painful moral } \\
\text { choices which include } \\
\text { trade-offs }\end{array}$ & $\begin{array}{l}\text { To be a patriot means } \\
\text { to question-when } \\
\text { necessary-political } \\
\text { institutions when they } \\
\text { run up against individual } \\
\text { conscience. Institutions } \\
\text { ought to be as "neutral" } \\
\text { as possible }\end{array}$ & $\begin{array}{l}\text { The United States as a } \\
\text { redeemer nation (led } \\
\text { by Captain America } \\
\text { no less!) }\end{array}$ \\
\hline Wolf Warrior & $\begin{array}{l}\text { Mostly this worldly, and } \\
\text { situated within physical } \\
\text { (earthly) reality. Choices } \\
\text { are more straight-for- } \\
\text { ward and is mostly due } \\
\text { to necessity }\end{array}$ & $\begin{array}{l}\text { To be a patriot means } \\
\text { to swear allegiance } \\
\text { to China even if it } \\
\text { means running against } \\
\text { individual conscience. } \\
\text { Institutions are highly } \\
\text { politicized }\end{array}$ & $\begin{array}{l}\text { Whoever is on China's } \\
\text { side is safe. The idea } \\
\text { of universal redemp- } \\
\text { tion is missing }\end{array}$ \\
\hline
\end{tabular}

“responsible great power" (fuzeren daguo, 负责任大国)—a phrase that has been a key motif in the Chinese foreign policy lexicon and discourse since President Xi came into power [15]. Indeed, this idea of a responsible great power fulfilling its international obligations is a central motif in Wolf Warrior 2 in which the male protagonist Leng Feng was sent to Africa as a security officer for freight services delivering relief supplies. In relating to the earlier three themes that I have discussed, namely, good-and-evil, patriotism, and redemption, Wolf Warrior 2 provides us with some salient insights into the nature of Chinese society and the type of idealized values that are operative in China. In doing so, I will also make reference to Avengers so as to highlight similarities and differences where they exist. (This will be summarized in Table 1.)

Unlike the Avengers, the Wolf Warrior movies situate conflict and war as an entirely this-worldly construct, one that eschews any notion of cosmic evil or metaphysical reality but instead is focused on the here-and-now. While this provides a film with greater realism as compared to Avengers (which involve intergalactic space travel), the idea that actors (no pun intended) can make meaningful moral choices to decide is also missing. As the hero, Leng is obviously on the side of good, but unlike Avengers, the right actions Leng take are mostly framed in a manner that does not require him to struggle against his own conscience or having to go up against more expedient choices. In other words, Leng's actions are a result of him being placed in circumstances in which the overwhelming need for survival necessitates certain actions to be taken. Unlike the characters in the Avengers who had to make the choice to save the world and to extract themselves from their lives of stability, the choice that is offered to Leng is far more straight-forward and poses less of a moral dilemma. To some extent such a portrayal of the fight between good and evil also reflects a highly pragmatic ethos that pervades Chinese political life, one that is less influenced by missionizing impulse and more of preserving the existing political status quo. In both the Wolf Warrior films, Leng Feng is shown as intervening 
only because he has to, not because he wants to. Such a mindset squares well with Chinese political worldview in China is often portrayed as acting in defense of its interests rather than being on the offensive to secure its interests [12, 22]. By casting its actions as largely defensive in nature (safeguarding Chinese interests from a belligerent and hostile external environment, China is able to negate - or at least partly deflect - the criticism that its actions are for offensive or expansionary purposes. As President Xi himself puts it during the 2021 National People's Congress, "The current security situation of our country is largely unstable and uncertain. The entire military must coordinate the relationship between capacity building and combat readiness, be prepared to respond to a variety of complex and difficult situations at any time, resolutely safeguard national sovereignty, security and development interests, and provide strong support for the comprehensive construction of a modern socialist state." 16

Secondly, the notion of patriotism as fleshed out in Wolf Warrior is also one which sees loyalty to China and the CPC as an absolute (or ultimate) value, one which all Chinese citizens ought to unswervingly preserve. While reference to the CPC is absent from the Wolf Warrior films, the fact that the CPC plays an outsized role in Chinese foreign policy and international politics is not without dispute: the stories of China and the CPC are joined together at the hip and interwoven in ways that one cannot exist without the other. As Kerry Brown writes, "From 1949, there is little daylight between the CPC story and the national one. The two became intimately linked...the Party argued it had achieved the salvation of the country. It was the entity that helped China throw off the heavy burden of its imperial pasts" [6]. One particular scene in Wolf Warrior 2 poignantly bears this out, albeit in a highly subtle manner. Early in the movie, Leng Feng and members of his special-ops team bring the remains of a fellow comrade back to his home town for the funeral only to see the homes there on the verge of being torn down completely. After being rudely confronted by the Chinese boss of the real estate company-the capitalist enemy who is portrayed as being greedy and lacking in empathy-who also boasts that he will make the family wish they were dead, an enraged Leng kicks the boss in his stomach and ends up killing him. Leng is sent to prison and discharged from the military. The scene then cuts into Leng being stripped of his rank and other military privileges; however, the narrator (which we presume refers to Leng's own voice and thought) goes on to say "the reason a soldier is respected is not because of the uniform he wears, but because of the sense of duty he carries. With or without the uniform, his duty remains. And he continues to be respected." In my view, this statement seems to suggest that a soldier's allegiance is not merely to the military, but that he is called to a higher duty, which is presumably (although the movie does not say it) that of the nation, and the party. This is a sharp point of contrast from many militaries around the world in which a soldier is respected because of the institution (the military) and the uniform that confers legitimacy to a soldier's actions. In the

\footnotetext{
${ }^{16}$ Wong, Catherine, "Xi Jinping Tells China's Military Be Prepared to Respond in Unstable Times," South China Morning Post, March 9, 2021, https://sg.yahoo.com/news/xi-jinping-tells-china-military111813369.html (retrieved March 12, 2021).
} 
case of Wolf Warrior 2, the actions of Leng are seen to be legitimate not because they are professionally mandated but because of a higher allegiance and sense of duty that Leng is obliged to serving. Seen this way, one might argue that the idea of patriotism - in the Chinese understanding - transcends institutional restraints and professional obligations. As a point of contrast in the Avengers series, both Iron Man and Captain America in Captain America: Civil War break ranks with one another precisely because both men had different views of what a patriot means. While Iron Man viewed his loyalties with the international community, Captain America perceived global institutions and bureaucracies as being essentially limiting (even corrupt) and thus chose to take matters into his own hands. Such a moral tension does not exist in Wolf Warrior nor are they framed as necessary. In the Chinese political worldview, institutions (especially the military) are designed to serve the party, and do not possess an institutional mind of their own, including the ability to "speak truth to power." ${ }^{17}$ Hence, Leng Feng-despite facing military prosecution-is exonerated in spirit because of his duty to a higher calling and consequently exemplifies the qualities of what a true Chinese patriot is all about: devotion to the Party.

Finally, and this is where Wolf Warrior fundamentally differs from Avengers: a conspicuous absence of the idea of universal redemption. Indeed, my above two points have highlighted a highly particularistic and this-worldly character to the Chinese political worldview, one which is less enamored with the attainment of universal salvation and instead is trained on "saving the nation" (jiuguo 救国) and instead, as a means of remedying the memory of national humiliation (guochi国耻). Indeed, this emphasis on the here-and-now as opposed to matters of eternal destiny is seen in the Confucius saying that "if I do not know the things of life, how can I know the things after death” (weizhisheng yanzhisi 未之生 焉知死). Seen this way, the notion of redemption in the Chinese worldview-this essay contends-is seen not in a future secular Eden (the idea of a future paradise on earth derived from Christian eschatology which continue to influence American popular thinking), but rather the return to a glorious idealized historical past in which China was once great and lost its place due to Western aggression and humiliation. As explained by a Lowy Institute study on the Chinese worldview, this narrative pushes the idea that "China was a powerful, respected, and peaceful global actor in the past, and this will once again be its natural and rightful role in the future. However, just as hostile international forces encircled China and pushed it from this position during the century of humiliation, these forces will continue trying to keep China down." "18 One way of responding to these external forces of aggression is the notion of "cleansing of humiliation" or "revenge" (xuechi 雪耻) which is also Chinese citizens are exhorted

\footnotetext{
17 What I have in mind are the events leading up to the 2020 American elections where a number of senior military officers criticized President Trump while serving in the military, thus indicating their ultimate loyalty to the Constitution, not the president or the party. For a classic exposition into Chinese bureaucracy and political institutions, see, Pye, Lucian W. The Mandarin and the Cadre: China's Political Cultures. Ann Arbor: University of Michigan Press, 1988.

18 Varrall, Merriden. "Chinese Worldviews and China's Foreign Policy." Lowy Institute, November 26, 2015, https://www.lowyinstitute.org/publications/chinese-worldviews-and-china-s-foreign-policy (retrieved March 13, 2021).
} 
to be "strong and powerful" [7]. In this way, China portrays its actions as that of acting in self-defense, not unlike most countries (including the United States), thus proffering the Chinese Communist Party with the moral high ground with which to frame its political behavior within and to sustain its identity as the ultimate defender of the Chinese nation. As Callahan observes, the narrative of national humiliation never ends and proclaiming National Humiliation Day continues to be a "political act that constructs identity and security long after the century of National Humiliation ended in 1949" [7].

Seen this way, political slogans such as President Xi's "rejuvenation of the great Chinese nation" (zhongguo de weida fuxing 中国的伟大复兴) are meant to be understood in a historical sense, in which $\mathrm{Xi}$ is simply claiming a political mandate that is historically legitimate and which reflect the hopes and aspirations of all Chinese, which is to see the revival of China to the status of its glorious past. Linked to this then is the notion that China seeks not to conquer or to get involved in the affairs of others, since the international system back then was different from present arrangements. This allows China to claim a superior form of morality and exceptionalism vis-à-vis the West: China is good because it does not seek to conquer, the West is bad because it conquers in the name of redeeming others. Furthermore, as the storyline of Wolf Warrior 2 shows us, any involvement of China in global affairs is framed in a manner in which China is not shown as an aggressor, but rather as a form of self-defense in respond to external aggression. At the same time, given China's global reach and considerations of great power responsibility (as I have earlier discussed), it is impossible for China for Beijing to be utterly untouched by what happens outside its borders (assuming there was even a period in its imperial history where it did not get involved in the affairs of others outside its borders).

Hence, one way to do so, as Wolf Warrior 2 has shown us, is to present China as a reluctant but trustworthy leader who is able to provide security to others under its care, in contrast to the United States, which is seen as a self-proclaimed but ultimately untrustworthy leader whose own narrow interests lead it to abscond from the theater of conflict. In a dialogue between Leng Feng and a humanitarian doctor Rachel Smith (played by Celina Jade) shortly after their escape from their killers, Smith wanted to go to the American Consulate to seek protection and added that "the US marines are stationed there. That's our safest bet." In response, Leng asked her whether "you think the US marines are the best in the world [and] where are they now?" When Smith said that she had already informed the embassy of the situation through a tweet, Leng remained silent before Smith proceeded to make a phone call instead. Instead, there was a recorded message saying that "we are closed" and causing Smith to scream "fuck," and Leng having the last laugh, literally.

\section{Conclusion}

Summing up the differences between the Avengers movie and Wolf Warrior (in Table 1), this essay contends that the differences of in the worldviews of the United States and China are central to the existing debate concerning geopolitical competition between both countries. As Shambaugh observes, this "comprehensive 
competition" between both countries reflects a "seismic shift in American thinking about China in recent years." Such deep-rooted differences in this author's view cannot be explained simply by recourse to elite manipulation of public opinion (although this may be true to a larger degree in China than the United States) nor due to competition over material resources or even because of international geopolitical rivalry. Rather, these differences arise as a result of more basic fundamental assumptions concerning self-other identities and how political actors understand their own respective countries' national interests and how these are related to everyday practices and political discourse.

That said, I am not suggesting that the differences within Avengers: Endgame and Wolf Warrior movies are ultimately deterministic of the future trajectory of SinoAmerican relations. Indeed, both movies seem to hint that what happens in the reel world may have surprising insights for the real world even if they were not originally intended. In Avengers: Endgame, the death of Iron Man provides some kind of closure for many of the characters that involved in the earlier apocalyptic conflict, particularly Captain America who eventually decides to pass on the mantle of leadership (as epitomized by the handing over of his shield) to Sam Wilson ("Falcon") and returning to the past to live with his lover Peggy Carter. Likewise in the final scenes of Wolf Warrior 2, Leng Feng-whose prime reason for being in Africa was to also locate the killer of his lover Long Xiaoyun-was also allowed to return to his military squadron while also shown a video that Long might be still alive. Both these scenes hint at the possibility of personal redemption and that individuals can continue to make meaningful choices even as they are placed amidst the events of war and conflict around them.

In the same way, geopolitical rivalry-while undoubtedly important to our discussion of international politics and political reality-is not everything. As this essay has shown, the political and personal, international conflict and interpersonal relations can often intertwine in surprising ways, thus suggesting that the agencystructure problematic remains very much valid. To this end, movies-be it made in Hollywood or China-may continue to surprise us with their insights, challenging us to consider their relevance in making sense of global politics, and that the storylines they purport to narrate not being far removed from the nature of great power competition.

\section{References}

1. Bellah, R.N. (1987). Habits of the Heart: Individualism and Commitment in American Life. New York: Harper \& Row.

2. Biden, J. (2020). Why America Must Lead Again: Rescuing U.S. Foreign Policy After Trump" Foreign Affairs 99( 2), 64-76.

3. Bleiker, R. (2001). The Aesthetic Turn in International Political Theory, Millennium - Journal of International Studies 30 (3), 509-533.

4. Bleiker, R. (2017). In Search of Thinking Space: Reflections on the Aesthetic Turn in International Political Theory, Millennium - Journal of International Studies 45(2), 258-264.

5. Boyce, J. (2015). Born Bad: Original Sin and the Making of the Western World. Berkeley, CA: Counterpoint Press. 
6. Brown, K. (2018). China's Dream: The Culture of Chinese Communism and the Secret Sources of its Power. Cambridge, UK: Polity Press.

7. Callahan, W.A. (2006). History, Identity, and Security: Producing and Consuming Nationalism in China, Critical Asian Studies 38(2), 179-208.

8. Callahan, W.A. (2020). Sensible Politics: Visualizing International Relations. New York: Oxford University Press.

9. Campbell, D. (2003). Cultural Governance and Pictorial Resistance: Reflections on the Imaging of War, Review of International Studies 29, 57-73.

10. Campbell, K. \& Sullivan, J. (2019). Competition Without Catastrophe: How America Can Both Challenge and Co-exist With China. Foreign Affairs 98(5), 96-110.

11. Furman, D.J. \& Musgrave, P. (2017). Synthetic Experiences: How Popular Culture Matters for Images of International Relations, International Studies Quarterly 61 (3), 503-516.

12. Feng, H. (2005). The Operational Code of Mao Zedong: Defensive or Offensive Realist? Security studies 14(4), 637-662.

13. Grady, M. \& Magistrale. T. (2016). The Shawshank Experience: Tracking the History of the World's Favorite Movie. New York: Palgrave Macmillan.

14. Grayson, K., Davies, M. \& Philpott, S. (2009). Pop Goes IR? Researching the Popular CultureWorld Politics Continuum, Politics 29 (3), 155-163.

15. Hoo, T.B. (2018). China's Global Identity: Considering the Responsibilities of Great Power. Washington, DC: Georgetown University Press.

16. Kennedy, C. (2013). The Manichean Temptation: Moralising Rhetoric and the Invocation of Evil in US Foreign Policy, International Politics 50 (5), 623-638.

17. Mandelbaum, M. (2002). The Ideas That Conquered the World: Peace, Democracy, and Free Markets in the Twenty-First Century (1st ed.). New York: Public Affairs.

18. Martin, P. (2021). China's Civilian Army: The Making of Wolf Warrior Diplomacy. New York: Oxford University Press.

19. McKenna, G. (2007). The Puritan Origins of American Patriotism. New Haven: Yale University Press.

20. Parmar, I. \& Cox, M. (2010). Soft Power and US Foreign Policy : Theoretical, Historical and Contemporary Perspectives. London: Routledge.

21. Preston, A. (2012). Sword of Spirit, Shield of Faith: Religion in American War and Diplomacy. Cambridge: Cambridge University Press.

22. Raditio, K.H. (2015). China's Shifting Behaviour in the South China Sea: A Defensive Realist Perspective, American Journal of Chinese studies 22 (2), 309-328.

23. Sachleben, M.A. (2014). World Politics on Screen: Understanding International Relations through Popular Culture. Lexington: The University Press of Kentucky.

24. Shapiro, M.J. (2006). The Sublime Today: Re-Partitioning the Global Sensible, Millennium - Journal of International Studies 34(3), 657-681.

25. Shapiro, M.J. (2009). Cinematic Geopolitics. London: Routledge.

26. Shulman, G. (2004). American Prophecy: Race and Redemption in American Political Culture. Minneapolis: University of Minnesota Press.

27. Solzhenitshn, A. (1975). The Gulag Archipelago. New York: Harper and Row.

28. Tan, S.S. (2017). Providing for the Other: Rethinking Sovereignty and Responsibility in Southeast Asia, Critical Studies on Security Vol.5 (3), 270-286.

29. Yan, X. (2014). From Keeping a Low Profile to Striving for Achievement, The Chinese Journal of International Politics 7 (2), 153-184.

30. Zhao, S. (2021). Rhetoric and Reality of China's Global Leadership in the Context of Covid-19: Implications for the US-led World Order and Liberal Globalization, Journal of Contemporary China, Vol. 30 (128), 233-248.

Publisher's Note Springer Nature remains neutral with regard to jurisdictional claims in published maps and institutional affiliations. 